\title{
Complaint Management 2.0 - The “Sag's uns” Blog as a Concept to Direct Democracy?
}

\author{
Gerald Fricke \\ UT Braunschweig \\ Mühlenpfordtstrasse 23, \\ 38106 Braunschweig
}

\author{
Yvonne Gaedke \\ UT Braunschweig \\ Mühlenpfordtstrasse 23, \\ 38106 Braunschweig
}

\author{
Robra-Bissantz \\ UT Braunschweig \\ Mühlenpfordtstrasse 23, \\ 38106 Braunschweig
}

\begin{abstract}
With students being part of the digital natives group the demand for more digital communication in universities is getting more and more important. To serve this matter the Technical University (TU) Braunschweig introduced "Sag's uns" (ger. Tell us), a blog where students can write their ideas, praises and complaints related to their field of study. In this way, Sag's uns even can be seen as a new way of corporate communications for universities. This paper focuses on how students are engaged in university processes in order to establish a democratic basic.
\end{abstract}

\section{Introduction}

The blog Sag's uns at TU Braunschweig was initiated in 2009 as a central web based platform for ideas, praise, criticism and complaints of all students of the university. Each participant has, working together with other students, the chance to write, to discuss and to initiate improvements related to studies and teaching at TU Braunschweig. The scope of this thesis is to outline the motivation to implement this blog and discuss whether it is a step towards more direct democracy.

\section{Blogs for corporate communications}

Since 2004 Web 2.0 stands for a number of interactive and collaborative internet elements. The users generate, edit and dispose contents in blogs wikis or micro blogs such as Twitter.

Also companies start entering this domain, mainly driven by the users. But the question is whether companies, scientific or cultural institutions should or should not blog at all?

First of all this is not a technical but a moral question.

Does the management or do the directors of universities trust their employees or students being

\footnotetext{
${ }^{1}$ http://www.tu-braunschweig.de/sagsuns
}

capable of autonomous blogging or is it necessary to control and monitor public statements? Only a few companies or universities got involved with the adventures of Corporate Blogs. One prominent example in Germany is the blog of the frozen food producer Frosta. In the Frosta-Blog, employees from different departments get a chance to talk about their work, their vacations or new adventures. The authors also face critical comments and discussions such as the company's pricing policy. Therefore a positive image transfer is anticipated. The direct and straight communication of a company with its customers, its pressmen or other disseminators of information seems to be more and more important [1]. The authors of Cluetrain Manifesto have already described which chances the web offers for a communicative company representation [3]. With Corporate Blogs, companies try to actively take part in the conversation of users and consumers about brands and products in Web 2.0. This way the positive and negative criticism is happening on their own web site. If the product brand or the quality is discussed unconcealed, the critics allow themselves to be convinced-and they may even become the company's supporters and ambassadors [10].

In order to meet the requirements of being up-to-date and relevant, blogs are used as a cover page of a company's or an institution's web site like for example the Department of Business Information Systems, Division Information Management at TU Braunschweig [5]. This department's blog serves as a model for the Sag's uns blog at TU Braunschweig.

\section{Blogs for complaint management 2.0}

The Sag's uns blog is part of a broad quality campaign at TU Braunschweig. In this context a complaint can be regarded as an expression of dissatisfaction, which is addressed towards the company as well as a third party [22]. The complaint management as a part of the Customer Relationship Management (CRM) tries to take up the articulated customer's dissatisfaction. The challenge is to develop an information technology system for complaint management which handles complaints 
and ideas from students in a transparent way and to ensure that students' contributions are moderated in order to make sure that discussed topics deal with fields of study and respect personal rights of employees and students. Besides the growing interest for using Web 2.0 technologies for corporate communications there are several reasons given in the literature of complaint management to support the idea to use a corporate blog. These reasons are classified as either direct complaint management, indirect complaint management or other settings [24].

\subsection{Direct complaint management}

The direct complaint management functions are complaint stimulating, complaint acceptance, complaint handling and complaint reaction [24]. For most companies the scope is to minimize the number of complaints, but this is the wrong way as complaints are a possibility to get constructive customers' feedback of products and services. So it is important to get and to use this information. There are several advices from the literature to improve the direct complaint management, which have been realized by implementing Sag's uns. In this paper following advices have been assigned to be part of the direct complaint management strategies. Complaints expressed by students should not be considered as inconvenient problems but as a welcomed approach for new ideas. By naming the service Sag's uns students should get the feeling that the university is willing to embrace complaints from student and offers a central point to place a problem, idea or praise [11;28]. Web 2.0 is an existing technologies used by the community to communicate and interact, so it is the university's duty to offer a Web 2.0 contact channel to students as a response to their needs [23, 25]. By offering a transparent and open discussion platform, the complaint's author has on the one hand the feeling that his complaint is taken seriously and that the process for complaining is authentic [8] and on the other hand it enables a dynamic information flow thus it is easier to identify deficits and improvement potentials [6]. The complaint process is easy to understand, to access and to follow up for everyone $[5,11,19]$. So it is sure that everyone, who is interested in the complaint process, is continuously informed about the status and gets the feeling that he or she can be sure that someone has taken care of the complaint [11]. By integrated them while working on a solution the complaint satisfaction can be increased [25]. A specially feature of Sag's uns is, that students can write their complaint anonymously so that they don't have to be afraid of possible negative consequences for their studies [11]. Furthermore the "traditional" way of complaint management-a complaint's author tells his complaint and gets an answer from the complaint owner - has changed. The solution is achieved by the whole community and everyone is able to answer [11], if he has the right solution. There is no clear classification between employee and student. Furthermore everyone is able to be an "experts" when he or she thinks that this is true for the problem discussed. The more people are discussing, the better the solution gets as people bring in their tacit knowledge [5].

\subsection{Indirect complaint management}

The indirect complaint management functions are analyzing complaints, complaint management controlling, complaint reporting and use of information [24]. Here the internal processes are more in the focus.

It is easier to prove if complaint's author is satisfied with the solution, by enable him to comment on the solution and given ideas. As the process is transparent everyone especially employees get continuously informed about existing grievances [11]. The people responsible for complaint management can both save time and money due to less telephone calls being necessary, less e-mails being answered, and less letters being exchanged $[4 ; 5 ; 17]$.

\subsection{Other settings}

In this category there are aspects dealing with strategic, human resource, organizational and technology aspects, which might be necessary to motivate participation and improve the quality of Sag's uns. The blog is supported by the university's leading board. This shows that the administration is open to feedback and participates in the discussion on Sag's uns, which is crucial for user acceptance [8; 11]. Additionally employees are a main source for improvements [11] and therefore they have an important "voice" in Sag's uns.

Web 2.0 technologies are known as very intuitive and most students have experiences with these tools this increases the motivation to use them. [8; 16]. Secondary it is only required to login once without having to provide any additional personal data, so the number of mandatory fields is very low [28].

Maximizing profit and increasing entrepreneurial competitiveness are generally considered to be primary goals for complaint management [24]. At TU Braunschweig, however, it is about the increase of the students' satisfaction by using the data from Sag's uns to ensure that quality in studies and teaching gets improved. 


\section{Realization of Sag's uns}

The idea blog was launched in the beginning of 2009 following the claim "by students for students". As mentioned below it is on purpose that the name is easy to remember and an invitation to tell complaints to the University - "Tell us". So the goal is described well and concisely: the students should not see the blog as a general agony column or reservoir of complaints but as a vital, open, and discursive platform of praise, ideas and criticism about their studies at TU Braunschweig.

During the preliminary stages all TU members were informed personally and invited to discuss in order to achieve a basic idea blog acceptance by all responsible persons at university. Simultaneously, an information and introduction campaign was started in the winter term of 2008/09 with posters, flyers and types of viral marketing, such as for example a satiric mobile phone movie. Furthermore, the university's press office supported the project actively and published the link on the university's web site.

First WordPress, a free weblog-publishingsystem was used which is based on the scripting language PHP and requires a MySQL database. In the course of the project WordPress turned out not to meet all demands which led to developing a blog engine by using Grails, a web framework inspired by Ruby on Rails. The Sag's uns blog can be integrated easily into the CMS (Content Management System) at TU Braunschweig and can be adjusted with the help of plug-ins.

The blog is constructed as a dyadic system: articles are not published immediately but being put on hold until they have been read by a moderator from the executive committee branch in order to assure that TU employees' and students' personal data remain protected. In problematic cases the author receives a message via email with the request to edit or adjust the article adequately.

If complainant attaches blame directly to a TU member, will he or she be at first approached by the moderator-and possibly is contacted directly. The goal is to reply to requests quickly but also to keep the internal communication channels of the TU in confidence. Of vital importance is the tagging of the articles. Using all tags a tag cloud is composed on the blog's front page. In an introducing text the users are asked to check if the tag cloud contains tags matching their topic (e.g. "room" or "project") to avoid duplicate topics being discussed. In this case the user is asked to read what other users have written about topics that are identified by the tags "room" and "project". Besides, the author assigns certain categories to the article. While everyone at TU is allowed to comment on existing articles, only students at TU are allowed to post new ones. To do so, the students have to log in with their user account which they have been given at enrolment by the data center.

Even without a registration it is possible to read entries-also by soon-to-be students, companies and the general public, who are able to observe the discussion of the students' problems-and the collective brain storming. This indirect pressure by the public does not prevent the goal to improve the studies and the teaching, but rather assists it. Not only students are asked to discuss in a polite and constructive way. It also requires a high level of media competence from the TU employees. The approach here is to introduce them to the tool and the idea behind the tool in a detailed way. Since the blog launched an increasing willingness between the employees to discuss online with students is noticed, while the whole world is listening.

According to the supposition linked to Habermas' [20] the entries and comments turn out to be more constructive and more solution-orientated and there are less disrespectful or impertinent entries and overhasty sweeping criticisms because of the public monitoring. Every panelist is aware of this public monitoring and will see himself or herself urged to act reasonable when replying to a factual, constructive reasoning even if he has a different opinion. This "evolution of cooperation" [2] can be observed in several discussions and most of the ideas do not fail to have the desired effect and also lead undifferentiated criticism in a solution-orientated direction.

In addition to that, entries may also be written anonymously in order to enable the users to express open criticism without revealing their own identityand thus to enable them to lead critical discussions. Nevertheless a registration is necessary. But the data confidentiality is guaranteed, because only the system "knows" which user wrote which article. Without a registration it cannot be ensured that the writer of an entry can be addressed directly-perhaps to inform him about the solution of a problem. If the blog author receives comments on his article, he is informed immediately via email in order to allow him to answer the comments as fast as possible-and in the best case to find a problem solution together with the panelists.

In order to incentivize the blog users to use the blog a prediction market is planned to be integrated, a future market on which the users are able to bet on their own or other's ideas. Like this the idea is determined which is from the users' point of view the one with the most prospective profit or the concept which generates in all probability the highest dividends [15]. The blog entry and its phrased suggestion or idea on which the most students bet wins-and the according suggestion is going to be realized. Hence, stimulation is created to propose ideas which are useful for most of the students. 
In the next step the problems discusses and the solutions found are evaluated empirically-with the help of user questioning and a qualitative content analysis among others with the method of "think loud" [18]. We want to figure out how the blog is used in reality, how an ideagora as a marketplace can be established and thus if our expressed demand for a direct democratic power of the Web 2.0 is realized. What does it mean?

\section{Discussion: Blogs as a new democratic way of "corporate communication"}

Let us turn our attention, once again, to Web 2.0. The theory of the "Wisdom of Crowds" [26] would mean, translated into the context of university, that maybe the multiplicity of students would offer "better" solutions than the experts of the university autonomy. But this wisdom of crowds is not necessarily the Volonté Générale, in terms of JeanJacques Rousseau [22]. At least, the common student is-in his role as an examinee, researcher or "customer" of the university-a hybrid character, whose knowledge and awareness is confronted in the university's daily routine with an individual benefit consideration. This benefit consideration is without a question opposed to the utilitarian awareness of a university as a public property. So we don't interpret Sag's uns as a paragon of wisdom for the use of general goods, but as a tool to capture the masses' knowledge and skills and to make it available to other users. According to the Wikinomics concept [27], ideagoras and idea blogs might bring together the knowledge of amateurs and experts and ideally connect the agents beyond the narrow borders of the own university. Ideagoras, idea blogs and democracy in Web 2.0 does not mean that actually everyone has to participate, but only the users who indeed want to be involved-and who are accepted as valuable and relevant panelists or even as opinion leaders by others.

By the help of this Sag's uns idea blog students get the chance to actively link information about their lives at the university. The phenomenon that students and citizens express their ideas by themselves and discuss them might have a deep and long-ranging impact on universities and democraticbased communities. In this context John Palfrey and Urs Gasser outline the philosophy of a semiotic democracy: "In a semiotic democracy the story of every citizen, [...] who possesses the necessitate internet access, will be reinterpreted and formed" [20]. Internet platforms or idea blogs create easier, more immediate, and faster than traditional types of cooperation subjective noticeable efficacy and the confidence that the individual's opinion is noticedand this opinion indeed "makes a difference" [18].
Furthermore, Sag's uns can also be viewed as a new and better way for the university's corporate communication in the age of Web 2.0 as well. Corporate communication is the communication issued by an organization to its public. It can be defined as the set of activities involved in managing and orchestrating all internal and external communications [3]. Facing the Web 2.0 and idea blogs such as Sag's uns, there is a great transformation from classic web sites, traditional public relations, and corporate content towards a new form of "Corporate Communications 2.0". What does this transformation mean? Facing the social web, institutions like universities have to listen first and then react. They have to trust their students, they have to think distributed and to be honest. Also university's web sites should work as platforms for students' and all members' needs and purposes, as described in Jeff Jarvis' thesis "What Would Google Do?” [9]. Idea and complaint blogs such as Sag's uns could be a blueprint for dealing better with students ideas, criticisms and complaints in an open and direct way at the universities' web sites. In this way, traditional web sites slightly transform into platforms. A platform for students helps others building value and creating products, businesses, communities, and networks of their own and for their university.

A university web site that includes an idea blog is not only about complaining, it is about a better way of consuming, producing and sharing corporate contents in the Web 2.0. If the university's communication staff and all students deal well with complaints at Sag's uns, this would be the best “corporate communication” in the Web 2.0 as well.

\section{Conclusion}

At first sight, an idea and complaint blog such as Sag's uns is only about an improved complaint management, a "customer loyalty” tool. Complaints are fast and easily expressed but the following discussions about specific improvement suggestions within a polis need a significantly higher commitment of some extremely active students. And exactly these students are going to leave the ideagora in the internet if they get the impression that the university's management only wants to improve the customer relationship.

In addition to that, those students who champion their university, who identify with it, who pay the tuition fee and possibly even develop a republican awareness for their university will not be content with the fact to discuss their suggestions "only" noncommittal. They want to see that their opinion, their entry in the idea blog "makes the difference". 
In this way a blog for ideas and complaints can be seen as a new and better way of "corporate communications” in the Web 2.0. Sag's uns stands for a major shift from marketing communication to conversational marketing, from public relations to "PR 2.0" and social media marketing. Even the university's brand image will be democratized. It isn't build only by the communications stuff any longer, but by the people and students who talk about and with their university.

What does result from this thesis? Democracy involves information, discussion and decision. By the help of the idea blog students can inform each other and discuss their improvement suggestions with the responsible TU members. But the final decision about which suggestions are going to be realized is reserved for the autonomy of the university-until further notice. In the future the central question besides the indirect codetermination on an idea market will be how a student's direct democratic exertion of influence on the representative based university institution could look like. And thus the general question will be if and how the Web 2.0 could complement and strengthen the representative democracy.

The debate to this is opened. "Sag's uns"!

\section{References}

[1] Alby T (2008) Web 2.0: Konzepte, Anwendungen, Technologien, Carl Hanser Verlag, München.

[2] Axelrod R (1984) The Evolution of Cooperation, New York.

[3] Bruhn M (2006) Integrierte Unternehmens- und Markenkommunikation, Schäffer-Poeschel, Stuttgart.

[4] Carlin, D (2007) Corporate Wikis Go Viral, in: Business Week Online,

http://www.businessweek.com/technology/content/mar200 7/tc20070312_476504.htm?c

han=search, 21.08 .2007$.

[5] Erz, A ; Tomczak, T (2008) Kollaboration im Web 2.0: Chancen für das Behavioral Branding. In: Interaktives Marketing. Wiesbaden : Gabler, 2008, S. 323-336.

[6] Günter, B (2001) Beschwerdemanagement als Schlüssel zur Kundenzufriedenheit, in: Homburg, Christian (2001): Kundenzufriedenheit: Konzepte - Methoden Erfahrungen, 4. Auflage, Wiesbaden, pp. 259-279.

[7] Habermas J (1971) Vorbereitende Bemerkungen zu einer Theorie der kommunikativen Kompetenz. In: Habermas J, Luhmann N: Theorie der Gesellschaft oder Sozialtechnologie, Suhrkamp, Frankfurt am Main, pp. 101141.

[8] Hansen, T; Wilke, R; Zaichkowsky, J (2010) Managing consumer complaints: differences and similarities among heterogeneous retailers. In International Journal of Retail
\& Distribution Management. Volume 38, Number 1, 2010 , pp. 6-23(18) Emerald Group Publishing limited. http://business.sfu.ca/files/Research/2010_Journal_Article s/Zaichkowsky_2010-Managing_consumer.pdf at 21.12.2010.

[9] Jarvis J (2009) What Would Google Do? Harper Collins, New York.

[10] Johnston R; Sandy M (2002): “Bestpractice complaint management”, Academy of Management Executive, 16 (4), pp. $145-154$.

[11] Kirby J, Marsden P (2005) Connected Marketing: The Viral, Buzz and Word of Mouth Revolution, Butterworth Heinemann.

[12] Leggewie C, Welzer H (2009) Das Ende der Welt, wie wir sie kannten, Fischer, Frankfurt/M.

[13] Levine R et al. (2000) The Cluetrain Manifesto, New York.

[14] Maciejovsky, B. ; Budescu, D. V. (2007) Collective induction without cooperation? Learning and knowledge transfer in cooperative groups and competitive auctions. Journal of Personality and Social Psychology, 92(5), 854870. doi: 10.1037/0022-3514.92.5.854.

[15] Manski CF (2005): Interpreting the Predictions of Prediction Markets, Department of Economics and Institute for Policy Research. http://www.aeaweb.org/annual_mtg_papers/2006/0106_10 15_0703.pdf.

[16] Matteson M.T. ; Ivancevich, J.M. (1982) Managing Job Stress and Health, The Free Press, New York, NY.

[17] McAfee, A.: Enterprise 2.0 - The Dawn of Emergent Collaboration. In: MIT Sloan Management Review, 47. Jg., 2006, Heft 3, pp 21-28.

[18] Mayring P (2003) Qualitative Inhaltsanalyse. Grundlagen und Techniken, 8. Aufl., Beltz UTB, Weinheim.

[19] Nambisan, S; Baron R (2007) "Interactions in Virtual Customer Environments: Implications for Product Support and Customer Relationship Management," Journal of Interactive Marketing, 21(2), 42-62.

[20] Palfrey J, Gasser U (2008) Generation Internet. Die Digital Natives: Wie sie leben, was sie denken, wie sie arbeiten, Hanser, München.

[21] Richter-Mundani S (1999) Kundenbindungssysteme für Kreditinstitute, Gabler, Wiesbaden, p 104.

[22] Rousseau JJ (2006 [1762]) Der Gesellschaftsvertrag oder Prinzipien des Staatsrechts, Wiesbaden.

[23] Scott, A (2005) Blogging and your Corporate Reputation: Part One - Listen to the Conversation.

Why PR and marketing pros need to monitor blogs on behalf of their organizations. 2005. www.Factiva.com. 
[24] Stauss B, Seidel W (2007) Beschwerdemanagement, Unzufriedene Kunden als profitable Zielgruppe, 4. Aufl., Carl-Hanser Verlag, München, p. 79.

[25] Stone, M (2009) Staying customer-focused and trusted: Web 2.0 and Customer 2.0 in fi nancial service. In: Journal of Database Marketing \& Customer Strategy Management (2009) 16, $101-131$.

[26] Surowiecki J (2004) The Wisdom of Crowds: Why the Many Are Smarter Than the Few and How Collective Wisdom Shapes Business, Economies, Societies and Nations, London.

[27] Tapscott D, Williams A (2008) Wikinomics: How mass collaboration changes everything, New York.

[28] Zaugg, D (2009) Why do consumers use the internet for complaining to the company? - Determinants Explaining the Propensity to Complain online. Key findings of the $\mathrm{PhD}$

thesis, http://www.onlinebeschweren.ch/Start/resource/Ma nagementSummary_OCCB_Zaugg.pdf. at 14.02.2011 